\section{Dietary patterns associated with anthropometric indicators of abdominal fat in adults}

\author{
Padrões alimentares associados a indicadores \\ antropométricos de adiposidade abdominal \\ em adultos
}

\author{
Patrones alimentarios asociados a los indicadores \\ antropométricos de adiposidad abdominal \\ en adultos
}

\author{
${ }_{1}$ Departamento de Alimentos \\ e Nutrição, Universidade \\ Federal de Mato Grosso, \\ Cuiabá, Brasil. \\ 2 Departamento de \\ Nutrição Social e Aplicada, \\ Universidade Federal do Rio \\ de Janeiro, Rio de Janeiro, \\ Brasil. \\ 3 Departamento de Medicina \\ Social, Universidade do \\ Estado do Rio de Janeiro, \\ Rio de Janeiro, Brasil. \\ Correspondence \\ A. A. F. Vilela \\ Departamento de Alimentos e \\ Nutrição, Universidade Federa \\ de Mato Grosso. \\ Av. Fernando Corrêa da Costa \\ 2367, Cuiabá, MT 78060-900, \\ Brasil. \\ anaameliafv@gmail.com
}

\begin{abstract}
This study aimed to identify dietary patterns and assess their association with abdominal fat. A cross-sectional study was conducted in the Central West Region of Brazil with a probabilistic sample of 208 adults of both sexes. Data on food intake was obtained using a food frequency questionnaire and factor analysis (principal components) was conducted to identify dietary patterns. Waist circumference (WC) and waistto-hip ratio (WHR) were used to assess abdominal fat. The association between dietary patterns and body fat distribution was examined using multiple linear regression analysis adjusted for confounders. Three dietary patterns were identified: Western, regional traditional, and prudent. A positive association was found between the Western pattern and WC $(p=0.04)$ and WHR ( $p=$ 0.001 ) and between the regional traditional pattern and WHR ( $p=0.05)$ among women. A slight association was also found between the latter pattern and $W C(p=0.07)$ also among women. An association was found between the Western and regional traditional dietary patterns and a larger concentration of abdominal fat among women.
\end{abstract}

Food Consumption; Statistical Factor Analysis; Waist Circumference; Waist-Hip Ratio; Adults

\author{
Ana Amélia Freitas Vilela 1,2 \\ Rosely Sichieri 3 \\ Rosângela Alves Pereira 2 \\ Diana Barbosa Cunha 3 \\ Paulo Rogério Melo Rodrigues 1 \\ Regina Maria Veras Gonçalves-Silva 1 \\ Márcia Gonçalves Ferreira 1
}

\section{Resumo}

Este estudo teve o objetivo identificar padrões alimentares e analisar a associação com a adiposidade abdominal. Estudo transversal, realizado na Região Centro-Oeste do Brasil, com amostra probabilística de 208 adultos, de ambos os sexos. O consumo alimentar foi obtido por questionário de frequência alimentar e aplicada análise fatorial (componentes principais) para identificar padrões alimentares. A circunferência da cintura (CC) e a relação cintura quadril (RCQ) foram indicadores de adiposidade abdominal. A associação dos padrões alimentares com adiposidade abdominal foi analisada em modelos de regressão linear múltipla ajustados por fatores de confusão. Identificaram-se três padrões alimentares: ocidental, tradicional regional e prudente. O padrão ocidental associouse positivamente com CC $(p=0,04)$ e RCQ $(p=$ $0,001)$ e o padrão tradicional regional associouse também com RCQ ( $p=0,05)$, e marginal a as sociação com a CC ( $p=0,07)$ somente em mulheres. Os padrões ocidental e tradicional regional associaram à maior adiposidade abdominal em mulheres.

Consumo de Alimentos; Análise Fatorial; Circunferência da Cintura; Relação CinturaQuadril; Adultos 


\section{Introduction}

Central adiposity is the accumulation of intra-abdominal fat in the trunk region. It is an important risk factor for disorders such as type 2 diabetes and cardiovascular disease and is considered to play a more significant role in the development of these diseases than the total amount of body fat $1,2,3,4$.

Accurate methods for assessing central adiposity, such as computed tomography scans and magnetic resonance imaging are costly and difficult to apply to epidemiological studies ${ }^{5}$. The World Health Organization (WHO) recommends anthropometric measurements as an adequate and accurate assessment method and waist circumference (WC) and waist-to-hip ratio (WHR) have been shown to be accurate indicators of abdominal fat 6 .

A number of studies on the association between dietary factors, particularly those related to nutrients and energy, and fat distribution have been conducted 7,8. However, the use of this approach limits investigation to the association between health outcomes and food intake ${ }^{9}$. Studies of dietary patterns have been shown to provide promising models for analyzing these associations because they have a greater focus on dietary recommendations and guidelines 10.

Dietary patterns can be defined as sets of foods commonly consumed by a specific population and may be described using food intake reports or methods for estimating food availability 11 . This approach provides a more realistic reflection of the food habits of the group of interest because it reveals the overall dietary pattern rather than isolated estimates of energy and nutrient intake or general food intake 12,13.

Factor analysis is a statistical method that is widely used to identify dietary patterns (or factors) that are not directly observable by aggregating original data on the consumption of several food items based on the existing dependency arrangement (represented by correlation and covariance between food items) 11,14 .

Published studies on the eating habits of the population of the Central West Region of Brazil have yet to identify dietary patterns among adults. The objective of the present study was therefore to identify dietary patterns among adults and evaluate their association with estimates of abdominal fat derived from anthropometric measurements.

\section{Materials and methods}

A sub-sample of a population-based survey conducted to estimate the prevalence of arterial hypertension among adults in Cuiabá the capital city of the State of Mato Grosso located in the Central West Region of Brazil 15 was used. All 686 adults of both sexes between 20 and 50 years of age were considered eligible for the evaluation using a food frequency questionnaire (FFQ) of which a total of 208 participants were randomly selected to answer questions on food consumption. The quantity of participants selected from each of the four zones of the city of Cuiabá was determined using the proportions adopted by the main study so as to ensure full coverage of the social makeup of the city. The study comprises a secondary analysis of food consumption data obtained by a FFQ validation study developed for use with adults in Cuiabá 16 .

The food items used to identify dietary patterns were obtained from a semiquantitative FFQ which included 81 food items and was based on a FFQ validated for use in the adult population of Cuiabá 16. Eight frequency of consumption options were offered: more than three times a day; twice to three times a day; once a day; five to six times a week; twice to four times a week; once a week; once to three times a month; and never or hardly ever. Frequency of consumption reported in the FFQ was converted into a daily frequency equivalent where proportionate values were attributed to the above frequency options based on a value of 1.0 for once-a-day; for example, twice to four times a week was equated to 0.43 times/ day. The chemical composition of each food item was defined based on the nutritional composition data contained in the NutWin software (Escola Paulista de Medicina, Universidade Federal de São Paulo, São Paulo, Brazil) which uses the food database of the United States Department of Agriculture with added food items from Brazilian Food Composition Table 17.

Guarana powder, garlic, onion and pepper were excluded from the analysis due to their low frequency of consumption or because they are used as spices and consumed with other prepared foods. The remaining 77 food items were divided into 21 food groups (Table 1) based on similarities in nutrient composition, particular dietary habits in the study population and frequency of consumption. Some of the commonly consumed food items reported by more than $80 \%$ were set apart (rice, beans, bread, sugar, coffee and butter/margarine).

Weight, height and waist and hip circumferences were measured using standard methods 18. Height was measured using a Seca 206 
Table 1

Food groups used in the factor analysis derived from the food frequency questionnaire. Cuiabá, State of Mato Grosso, Brazil, 2007.

\begin{tabular}{|c|c|}
\hline Food group & Foods from the food frequency questionnaire \\
\hline Rice & Rice \\
\hline Beans & Beans \\
\hline Cakes, cookies & Plain cakes, cakes with filling and topping/with fruit syrup, cookies-crackers, filled cookies, savory crackers \\
\hline Breads & French roll/loaf of bread \\
\hline Refined grains, roots and tubers & Baked/mashed potato, cassava, cassava flour and sweet potato/yam/yams \\
\hline Pasta & Pasta; pancakes/gnocchi/lasagna/ravioli \\
\hline Regional dishes & Baked rice/rice with meat/chicken with rice/pork with rice, pequi (souari nut), fried banana \\
\hline Fats & Butter/margarine \\
\hline Dairy products & Cheese, milk, cottage cheese, yogurt/cheese curds \\
\hline Meat and eggs & $\begin{array}{l}\text { Pork, beef, beef or chicken stroganoff/chicken bobó (dish made of highly-spiced chicken); barbecue, giblets } \\
\text { (gizzard, heart, liver, stomach/tripe, kidneys) and eggs }\end{array}$ \\
\hline White meat & Fish and chicken \\
\hline Sausages and deli meats & $\begin{array}{l}\text { Sausage, cold cuts (bologna, ham, fatty ham, salami and frankfurter), bacon, smoked pork loin, beef jerky, } \\
\text { canned corned beef }\end{array}$ \\
\hline Canned vegetables & Canned vegetables such as peas, corn, palm heart, olives \\
\hline Fruits & Orange/tangerine, banana, papaya, apple, watermelon, pineapple and mango \\
\hline Green vegetables and legumes & $\begin{array}{l}\text { Lettuce, cabbage/kale/chard, arugula/endive/watercress, cauliflower/broccoli, tomato, cucumber, chayote, } \\
\text { gherkin/eggplant, squash/zucchini, carrots, beets and okra/pod }\end{array}$ \\
\hline Sodas & Cola soft drinks and other soft drinks/guarana-flavored soft drink \\
\hline Juice and tea & Fruit juices/pulp and tea \\
\hline Coffee & Coffee \\
\hline Fast food & $\begin{array}{l}\text { Pizza, hot dogs, hamburgers, French fries/chips/mayonnaise, snacks, popcorn, fried salted pastries/pies and } \\
\text { cheese bread }\end{array}$ \\
\hline Sweets & $\begin{array}{l}\text { Ice cream or popsicles, candies, caramels, chewing gum, chocolate powder, chocolate bars/bonbon, fruit jam or } \\
\text { jelly or hard fruit molasses/milk molasses }\end{array}$ \\
\hline Sugar & Sugar \\
\hline
\end{tabular}

portable stadiometer (Seca, São Paulo, Brazil) with a $220 \mathrm{~cm}$ millimeter scale. Weight was measured using an electronic scale (Tanita, Model UM 080; Tanita, São Paulo, Brazil) with a $150 \mathrm{~kg}$ capacity and accurate to $0.1 \mathrm{~kg}$. Body mass index $\left(\mathrm{kg} / \mathrm{m}^{2}\right)$ was classified according to the WHO 6 categories to define weight status.

Waist and hip measurements were taken using an anthropometric tape (model Gulick, Mabb, Curitiba, Brazil) with a $150 \mathrm{~cm}$ millimeter scale following the recommendations of Callaway et al. 19. Height, waist and hip circumference were measured twice. A maximum difference of $0.5 \mathrm{~cm}$ for height and $1.0 \mathrm{~cm}$ for waist and hip circumferences was allowed between the first and the second measurements. WC was measured on the smallest abdominal curvature or at the midpoint between the iliac crest and the last rib when the former was difficult to identify.

Dietary patterns were identified using principal component factor analysis 11 based on the food items contained in the FFQ. A correlation matrix was constructed to determine the correlation between variables and the Kaiser-MeyerOlkin (KMO) test and Bartlett's test of sphericity were used to determine whether the assumptions used in the factor analysis were correct. Sampling is considered adequate when the KMO value is greater than 0.6 and when the $p$-value of Bartlett's test of sphericity is less than or equal to 0.05 11,20.

Principal component analysis was performed, followed by orthogonal rotation (varimax method). The criterion used for determining the number of factors to extract was an eigenvalue of $>1.514,21,22$. Food groups with factor loadings greater than 0.30 were retained in the identified patterns and the cut-off value for communality was set at 0.20 . The internal consistency of the extracted factors was determined using Cronbach's alpha ${ }^{11}$. A score was determined for each dietary pattern using principal components factor analysis. 
Multiple linear regression analysis was used to verify the association between the respondent's eating habits and the identified dietary patterns. The dependent variables were the dietary pattern scores and the independent variables were those which had a $\mathrm{p}<0.20$ in the linear regression analysis.

Multiple linear regression was carried out to analyze the association between abdominal fat indicators and dietary patterns using WC and WHR as dependent variables. The WC and WHR variables presented a symmetric distribution ( $p$ > 0.05; Kolmogorov-Smirnov test). The independent variables were the dietary pattern scores. The models were adjusted for age (years), smoking (smoker, former smoker and nonsmoker), alcohol consumption (consumption or nonconsumption during the last week), regular leisure physical activity classified as practicing (three or more leisure physical activities in the three months preceding the interview) or not practicing (no or up to two leisure physical activities in the three months preceding the interview) weekly physical activity, and socioeconomic status (SES) based on the categories adopted by the Brazilian Association of Market Research Companies (ABEP; http://www.abep.org/novo/De fault.aspx, accessed on 26/Jul/2011). The models were also adjusted for total energy consumption and BMI.

This study was approved by the ethics committee of the Júlio Müller University Hospital of the Federal University of Mato Grosso (application number 234/CEP/HUJM/05). Participants gave written informed consent after receiving details regarding the study.

\section{Results}

A total of 108 females and 100 males with a mean age of 33.7 years (standard deviation $=9.7$ ) were evaluated. The sample showed the following characteristics: $45.2 \%$ were from SES class B; $71.6 \%$ were nonsmokers; $66.8 \%$ consumed alcohol; $60.6 \%$ did not practice physical activity; $34.6 \%(n=72)$ were identified as being overweight $\left(\mathrm{BMI} \geq 25 \mathrm{~kg} / \mathrm{m}^{2}\right)$; and $19.2 \%(\mathrm{n}=40)$ were obese (BMI $\geq 30 \mathrm{~kg} / \mathrm{m}^{2}$ ) (Table 2 ).

Mean WC and WHR among women was 80.1cm (95\%CI: 78.0-82.2) and 0.79 (95\%CI: 0.78$0.80)$, respectively, while among men, mean WC and WHR was $90.6 \mathrm{~cm}$ (95\%CI: 88.1-93.1) and 0.88 (95\%CI: 0.87-0.90), respectively (data not shown).

The KMO coefficient (0.621) and p-value of Bartlett's test of sphericity $(\mathrm{p}<0.001)$ showed sufficient and adequate correlation between data in the factor analysis 11 . Three dietary patterns were identified that together accounted for $35 \%$ of explained variance. The first pattern, called "Western pattern", explained $14.9 \%$ of variance and included the food groups breads, pasta, fats, dairy products, sausages and deli meats, canned vegetables, sodas, fast food, and sweets. The second pattern, called "regional traditional", explained $10.5 \%$ of variance and included mainly rice, beans, refined grains and tubers, regional dishes, meat and eggs, coffee, and sugar. The third pattern, called "prudent", was characterized by the consumption of fruits, green vegetables and legumes, white meats, juices and tea, and cakes and cookies/crackers and explained $9.6 \%$ of variance. This pattern was labeled "prudent" because all items, except cakes and cookies/crackers, are considered part of a healthy diet. Commonality $\left(\mathrm{h}_{2}=0.20\right)$ and the factor loadings $(0.30)$ were greater than the acceptable values. Cronbach's alpha was 0.61 for the "Western" and "regional traditional" patterns and 0.41 for the "prudent" pattern (Table 3).

Table 4 shows that high energy consumption in young adults was associated with the "Western" pattern. Being a nonsmoker and having a low BMI was associated with the "regional traditional" pattern, and practicing physical activity, being a nonsmoker and having high BMI was associated with the "prudent" pattern. A positive association was found between the "Western" pattern and WC $(\beta=1.11, \mathrm{p}=0.04)$ and WHR $(\beta=$ $0.02, p=0.001$ ) among women. The "regional traditional" pattern was associated with WHR ( $\beta=$ $0.01, p=0.05$ ) and a slight association was found between this pattern and WC $(\beta=0.87, \mathrm{p}=0.07)$ (Table 5).

\section{Discussion}

Three dietary patterns were identified among this sample of adults using principal component analysis: "Western"; "regional traditional"; and "prudent". The percentage of variance explained found in the three dietary patterns was consistent with that identified in other studies (for example Neumann et al. 23 35.6\%, and Cunha et al. $2434.9 \%$ ) and lower than the values observed by other studies, such as Sieri et al. 13 (30\%) and Kjøllesdal et al. 25 (20\%). While a positive association was observed between the "Western" and "regional traditional" dietary patterns and abdominal fat, no significant association was found between the "prudent" pattern and anthropometric indicators of abdominal fat.

A positive association was found between the "Western" pattern, characterized by a high intake of fat and carbohydrates, and increased WC and 
Distribution of respondents according to sociodemographic characteristics, lifestyle and weight status. Cuiabá, State of Mato Grosso, Brazil 2007.

\begin{tabular}{|c|c|c|}
\hline Variables & $\mathbf{n}$ & $\%$ \\
\hline \multicolumn{3}{|l|}{ Gender } \\
\hline Male & 100 & 48.1 \\
\hline Female & 108 & 51.9 \\
\hline \multicolumn{3}{|l|}{ Age (years) } \\
\hline $20-29$ & 87 & 41.8 \\
\hline $30-39$ & 56 & 26.9 \\
\hline $40-50$ & 65 & 31.3 \\
\hline \multicolumn{3}{|c|}{ Socioeconomic status } \\
\hline Class A & 22 & 10.6 \\
\hline Class B & 94 & 45.2 \\
\hline Class C & 78 & 37.5 \\
\hline Class D & 14 & 6.7 \\
\hline \multicolumn{3}{|l|}{ Smoking } \\
\hline Smoker & 30 & 14.4 \\
\hline Former smoker & 29 & 13.9 \\
\hline Nonsmoker & 149 & 71.6 \\
\hline \multicolumn{3}{|c|}{ Alcohol consumption } \\
\hline \multicolumn{3}{|l|}{ (last week) } \\
\hline Yes & 139 & 66.8 \\
\hline No & 69 & 33.2 \\
\hline \multicolumn{3}{|c|}{ Leisure physical activity } \\
\hline \multicolumn{3}{|l|}{ (last three months) } \\
\hline Yes & 82 & 39.4 \\
\hline No & 126 & 60.6 \\
\hline \multicolumn{3}{|c|}{ Weight status assessment } \\
\hline Under weight & 6 & 2.9 \\
\hline Normal weight & 90 & 43.3 \\
\hline Overweight & 72 & 34.6 \\
\hline Obese & 40 & 19.2 \\
\hline
\end{tabular}

WHR among women. Studies have shown a positive association between a high intake of fat (saturated, monounsaturated or polyunsaturated) and central adiposity 26 . A study conducted in Brazil by Neumann et al. 23 showed an association between the consumption of foods labeled as the "coffee shop/cafeteria" pattern - whole milk, bread, pasta, snacks, sweets, fats, ham, artificial juices, sodas, and, to a lower extent, feijoa$d a$ (stew of beans with pork), natural juices and chicken - was associated with increased WHR. Eating habits are influenced by cultural, social and demographic factors 9 . Lifestyle changes, socioeconomic factors and easy access to processed foods have all contributed to changes in eating habits over time leading to a high intake of protein, fat and refined carbohydrates 23,25,27.
The "regional traditional" pattern comprised food items and food dishes typical to the study region (fried banana, rice dishes and pequi, or souari nut) and foods traditionally consumed by the Brazilian population (rice and beans). Similar patterns were identified by other studies undertaken in Brazil 9,24,28. Dietary pattern studies have shown that these foods are part of the traditional dietary pattern which has a protective effect on BMI, WC and WHR 23,24,28. However, the present study found a positive association between WHR and the traditional dietary pattern identified by this study, called the "regional traditional" pattern, among women. It should be noted that this pattern included other foods considered typical to the region studied which are not included in the traditional pattern described by other studies conducted in Brazil 24,28. This factor may have contributed to this association since some of these food items are rich in fat and have a high energy density (for example, fried banana and some rice dishes). The "regional traditional" pattern identified by this study also included sugar, which may contribute to an increased accumulation of abdominal fat 29 .

Contrary to the general literature, a protective effect of the "prudent" pattern ${ }^{30}$ on abdominal adiposity was not observed by this study. Although the "prudent" pattern consisted of mainly healthy foods, such as white meat, fruits, vegetables, juices and tea, it also included cakes and cookies/crackers, which are not considered healthy because they contain high levels of trans fatty acids, particularly crackers 31 which also have a high sodium content. Another possible explanation is that those subjects with these eating habits adhered to this dietary pattern due to conditions that led them to adopt a healthier diet. It is interesting to note that those individuals that adhered to this pattern had high BMI, were nonsmokers and reported practicing physical activity, showing that adherence to this diet pattern is probably a result of health problems and/ or weight loss efforts. Rossi et al. 32 also found that there was no significant association between WC and the Mediterranean diet pattern, which is characterized by foods that are considered to be healthy.

A limitation of this study is the cross-sectional nature of the design which may make it susceptible to reverse causality and explain the lack of association between the protective effect of the "prudent" pattern and abdominal fat. The sample size is considered sufficient for a principal component analysis to identify dietary patterns. The required sample size is between five and 10 subjects per variable included in the model 11. In this study the food items in the 
Distribution of factor loadings and commonalities $\left(h_{2}\right)$ of the three dietary patterns identified by the study. Cuiabá, State of Mato Grosso, Brazil 2007.

\begin{tabular}{|c|c|c|c|c|}
\hline \multirow[t]{3}{*}{ Food groups } & \multicolumn{4}{|c|}{ Factor loadings } \\
\hline & \multicolumn{4}{|c|}{ Three-factor solution } \\
\hline & "Western" & $\begin{array}{l}\text { "Regional } \\
\text { traditional" }\end{array}$ & "Prudent" & $\mathrm{h}_{2}$ \\
\hline Breads & 0.55 & & & 0.53 \\
\hline Pasta & 0.53 & & & 0.30 \\
\hline Fats & 0.51 & & & 0.50 \\
\hline Dairy products & 0.37 & & & 0.21 \\
\hline Sausages and deli meats & 0.69 & & & 0.47 \\
\hline Canned vegetables & 0.62 & & & 0.23 \\
\hline Sodas & 0.53 & & & 0.40 \\
\hline Fast food & 0.44 & & & 0.31 \\
\hline Candies & 0.50 & & & 0.31 \\
\hline Rice & & 0.75 & & 0.57 \\
\hline Beans & & 0.71 & & 0.51 \\
\hline Refined grains and tubers & & 0.37 & & 0.21 \\
\hline Regional typical dishes & & 0.46 & & 0.41 \\
\hline Meat and eggs & & 0.41 & & 0.31 \\
\hline Coffee & & 0.54 & & 0.30 \\
\hline Sugar & & 0.53 & & 0.33 \\
\hline Cakes and cookies-crackers & & & 0.36 & 0.20 \\
\hline White meat & & & 0.48 & 0.26 \\
\hline Fruits & & & 0.58 & 0.35 \\
\hline Green vegetables and legumes & & & 0.60 & 0.36 \\
\hline Juices and tea & & & 0.49 & 0.28 \\
\hline Number of items & 9 & 7 & 5 & \\
\hline Eigenvalues & 3.13 & 2.21 & 2.01 & \\
\hline Percentage of explained variance & 14.89 & 10.50 & 9.58 & \\
\hline Percentage of explained cumulative variance & 14.89 & 25.39 & 34.97 & \\
\hline Cronbach's alpha & 0.61 & 0.61 & 0.41 & \\
\hline
\end{tabular}

FFQ were aggregated into 21 food groups, which is equivalent to a sample size requirement of between 105 and 210 individuals and this study therefore meets the sample size requirements. Factor analysis is also limited because the researcher must make several arbitrary decisions regarding the selection of variables, retained factors and names assigned to the retained factors. Despite these limitations, this method is widely used in national and international studies to identify dietary patterns $13,24,28,33,34$.

This study did not identify any association between the dietary patterns and abdominal obesity among men suggesting that it is possible that diet has a greater effect on central fat distribution in women than in men. This study demonstrated a statistically significant positive association between the "Western" and "regional traditional" dietary patterns and anthropometric measurements of body fat distribution among women. This finding suggests that the traditional diet patterns identified by previous studies were characterized by a lower variety of food items and lower energy intake. However, it should be noted that a recent association has been found between the traditional diet pattern and excess intake of other food items due to an increase in income and food availability. Therefore, the consumption of healthier foods should be promoted together with the control of total energy intake. 
Bivariate linear regression, multiple linear regression coefficients and associated p-values for dietary patterns and specific characteristics. Cuiabá, State of Mato Grosso, Brazil 2007.

\begin{tabular}{|c|c|c|c|c|c|c|c|c|c|c|c|c|}
\hline & \multicolumn{4}{|c|}{ "Western" pattern } & \multicolumn{4}{|c|}{ "Regional traditional" pattern } & \multicolumn{4}{|c|}{ "Prudent" pattern } \\
\hline & \multicolumn{2}{|c|}{$\begin{array}{l}\text { Bivariate linear } \\
\text { regression }\end{array}$} & \multicolumn{2}{|c|}{$\begin{array}{l}\text { Multiple linear } \\
\text { regression * }\end{array}$} & \multicolumn{2}{|c|}{$\begin{array}{l}\text { Bivariate linear } \\
\text { regression }\end{array}$} & \multicolumn{2}{|c|}{$\begin{array}{l}\text { Multiple linear } \\
\text { regression * }\end{array}$} & \multicolumn{2}{|c|}{$\begin{array}{l}\text { Bivariate linear } \\
\text { regression }\end{array}$} & \multicolumn{2}{|c|}{$\begin{array}{l}\text { Multiple linear } \\
\text { regression * }\end{array}$} \\
\hline & $\beta$ ** & $\mathrm{p}$-value & $\beta^{\star *}$ & $p$ value & $\beta$ ** & $\mathrm{p}$-value & $\beta$ ** & $p$-value & $\beta$ ** & $\mathrm{p}$-value & $\beta$ ** & $\mathrm{p}$-value \\
\hline Age (years) & -0.26 & $<0.01$ & -0.26 & $<0.01$ & 0.07 & 0.31 & 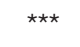 & 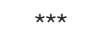 & 0.16 & 0.03 & $\#$ & \# \\
\hline $\begin{array}{l}\text { Leisure } \\
\text { physical } \\
\text { activity }\end{array}$ & -0.09 & 0.19 & $\#$ & $\#$ & 0.05 & 0.46 & 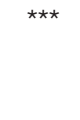 & 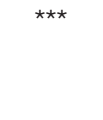 & 0.09 & 0.18 & 0.17 & 0.02 \\
\hline Smoking & 0.04 & 0.54 & 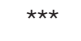 & 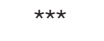 & -0.22 & $<0.01$ & -0.20 & 0.004 & -0.11 & 0.11 & -0.015 & 0.03 \\
\hline $\begin{array}{l}\text { Energy } \\
\text { consumption }\end{array}$ & 0.16 & 0.02 & 0.14 & 0.03 & 0.05 & 0.46 & 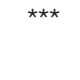 & 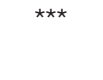 & -0.06 & 0.37 & *** & 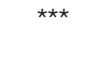 \\
\hline BMI & -0.08 & 0.28 & $\star \star \star$ & 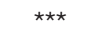 & -0.10 & 0.14 & -0.13 & 0.05 & 0.12 & 0.09 & 0.15 & 0.03 \\
\hline
\end{tabular}

BMI: body mass index.

* Model adjusted for gender;

** Standardized beta;

*** The variable was not significant in the bivariate linear regression analysis, p-value under 0.2 ;

\# No association was found for this variable in the multiple linear regression analysis.

Table 5

Regression coefficients, associated * $p$-values, and R2 for dietary patterns and waist circumference, and waist-to-hip ratio. Cuiabá, State of Mato Grosso, Brazil 2007.

\begin{tabular}{|c|c|c|c|c|c|c|}
\hline & \multicolumn{3}{|c|}{ Males } & \multicolumn{3}{|c|}{ Females } \\
\hline & $\beta$ ** & p-value & $\mathbf{R}^{2}$ & $\beta * \star$ & p-value & $\mathbf{R}^{2}$ \\
\hline \multicolumn{7}{|c|}{ "Western" pattern } \\
\hline$W C(\mathrm{~cm})$ & 0.11 & 0.82 & 0.86 & 1.11 & 0.04 & 0.85 \\
\hline WHR & 0.01 & 0.19 & 0.58 & 0.02 & 0.01 & 0.38 \\
\hline \multicolumn{7}{|c|}{ "Regional traditional" pattern } \\
\hline WC $(\mathrm{cm})$ & 0.56 & 0.30 & 0.86 & 0.87 & 0.07 & 0.86 \\
\hline WHR & 0.01 & 0.61 & 0.57 & 0.01 & 0.05 & 0.35 \\
\hline \multicolumn{7}{|c|}{ "Prudent" pattern } \\
\hline WC $(\mathrm{cm})$ & 0.55 & 0.36 & 0.86 & 0.28 & 0.50 & 0.84 \\
\hline WHR & 0.01 & 0.08 & 0.59 & 0.01 & 0.35 & 0.33 \\
\hline
\end{tabular}

WC: waist circumference; WHR: waist-to-hip ratio.

* Model adjusted for age, smoking, alcohol consumption, physical activity, socioeconomic status, body mass index and total energy consumption;

** Standardized beta. 


\section{Resumen}

Este estudio tuvo como objetivo determinar los patrones alimentarios y analizar su asociación con la adiposidad abdominal. Estudio transversal, realizado en la región centro-oeste de Brasil, con una muestra probabilística de 208 adultos de ambos sexos. El consumo alimentario se obtuvo en un cuestionario de frecuencia alimentaria y para determinar los patrones alimentarios se utilizó un análisis factorial (componentes principales). El perímetro de cintura (PC) y la relación cinturalcadera (RCC) indicaron adiposidad abdominal. La asociación de patrones alimentarios y adiposidad abdominal se analizó en modelos de regresión lineal múltiple, ajustados por factores de confusión. Se identificaron tres patrones alimentarios: occidental, tradicional regional y prudente. El occidental se asoció positivamente al PC $(p=0,04)$ y RCC $(p=0,001)$, el tradicional regional se asoció también a RCC $(p=0,05)$ y marginal la asociación al PC ( $p=0,07)$, sólo en mujeres. Los patrones occidental y tradicional regional se asociaron a una mayor adiposidad abdominal en mujeres.

Consumo de Alimentos; Análisis Factorial; Circunferencia de la Cintura; Relación CinturaCadera; Adultos

\section{Contributors}

A. A. F. Vilela participated in all aspects of the study, including the drafting of the manuscript, data analysis and interpretation. R. Sichieri and R. A. Pereira contributed to design, interpretation of data and the drafting of the manuscript. D. B. Cunha, P. R. M. Rodrigues and R. M. V. Gonçalves-Silva contributed to data analysis and interpretation, critical revision of the manuscript for important intellectual content, and the final approval of the published version. M. G. Ferreira participated in study design and coordination, data interpretation and the drafting of the manuscript.

\section{Acknowledgments}

The authors are grateful to Capes (research protocol number 23038.042868/2008-11) and CNPq (research protocol number $473390 / 2008-6$ ) for funding this research project.

\section{References}

1. Lemos-Santos MGF, Valente JG, Gonçalves-Silva RMV, Sichieri R. Waist circumference and waist-tohip ratio as predictors of serum concentration of lipids in Brazilian Men. Nutrition 2004; 20:857-62.

2. Chen CC, Wang WS, Chang HY, Liu JS, Chen YJ. Heterogeneity of body mass index, waist circumference, and waist-to-hip ratio in predicting obesity-related metabolic disorders for Taiwanese aged 35-64y. Clin Nutr 2009; 28:543-8.

3. Oliveira LPM, Assis AMO, Silva MCM, Santana MLP, Santos NS, Pinheiro SMC, et al. Fatores associados a excesso de peso e concentração de gordura abdominal em adultos na cidade de Salvador Bahia, Brasil. Cad Saúde Pública 2009; 25:570-82.

4. Sousa TF, Nahas VM, Silva DAS, Del Duca GF, Peres MA. Factors associated with central obesity in adults from Florianópolis, Santa Catarina: a population based-study. Rev Bras Epidemiol 2011; 14:296-309.

5. Dalton M, Cameron AJ, Zimmet PZ, Shaw JE, Jolley D, Dunstan DW, et al. Waist circumference, waisthip ratio and body mass index and their correlation with cardiovascular disease risk factors in Australian adults. J Intern Med 2003; 254:555-63.
6. World Health Organization. Obesity: preventing and managing the global epidemic. Geneva: World Health Organization; 1998. (WHO Technical Report Series, 894).

7. Roberts SB, McCrory MA, Saltzman E. The influence of dietary composition on energy intake and body weight. J Am Coll Nutr 2002; 21:140S-5S.

8. Rosenblum JL, Castro VM, Moore CE, Kaplan LM. Calcium and vitamin D supplementation is associated with decreased abdominal visceral adipose tissue in overweight and obese adults. Am J Clin Nutr 2012; 95:101-8.

9. Marchioni DML, Latorre MRDO, Eluf-Neto J, Wünsch-Filho V, Fisberg RM. Identification of dietary pattern using factor analysis in an epidemiological study in São Paulo. São Paulo Med J 2005; 123:124-7.

10. World Health Organization. Diet, nutrition and prevention of chronic diseases. Geneva: World Health Organization; 2003. (Technical Report Series, 916). 
11. Olinto MTA. Padrões alimentares: análise de componentes principais. In: Kac G, Sichieri R, Gigante DP, organizadores. Epidemiologia nutricional. Rio de Janeiro: Editora Fiocruz/Editora Atheneu; 2007. p. 213-25.

12. Hu FB. Dietary pattern analysis: a new direction in nutritional epidemiology. Curr Opin Lipidol 2002; 13:3-9.

13. Sieri S, Krogh V, Pala V, Muti P, Micheli A, Evangelista A, et al. Dietary patterns and risk of breast cancer in the ORDET cohort. Cancer Epidemiol Biomarkers Prev 2004; 13:567-72.

14. Artes R. Aspectos estatísticos de análise fatorial de escalas de avaliação. Rev Psiquiatr Clín 1998; 25:223-8.

15. Barbosa LS, Scala LCN, Ferreira MG. Association between anthropometric markers of body adiposity and hypertension in an adult population of Cuiabá, Mato Grosso. Rev Bras Epidemiol 2009; 12:237-47.

16. Silva NF, Sichieri R, Pereira RA, Gonçalves-Silva RMV, Ferreira MG. Reproducibility, relative validity and calibration factors of a food frequency questionnaire designed for adults. Cad Saúde Pública 2013; 29:1783-94.

17. Núcleo de Estudos e Pesquisas em Alimentação, Universidade do Estadual de Campinas. Tabela brasileira de composição de alimentos. 2a Ed. Campinas: Núcleo de Estudos e Pesquisas em Alimentação, Universidade do Estadual de Campinas; 2006.

18. Gordon CC, Chumlea WC, Roche AF. Stature, recumbent length, and weight. In: Lohman TG, Roche AF, Martorell R, editors. Anthropometric standardization reference manual. Champaign: Human Kinetics Books; 1988. p. 3-8.

19. Callaway CW, Chumlea WC, Bouchard C, Himes JH, Lohman TG, Martin AD, et al. Circumferences. In: Lohman TG, Roche AF, Martorell R, editors. Anthropometric standardization reference manual. Champaign: Human Kinetics Books; 1988. p. 3954.

20. Pereira JCR. Análise de dados qualitativos: estratégias metodológicas para as ciências da saúde, humanas e sociais. São Paulo: Edusp; 1999.

21. Sichieri R, Castro JFG, Moura AS. Fatores associados ao padrão de consumo alimentar da população brasileira urbana. Cad Saúde Pública 2003; 19 Suppl 1:S47-53.

22. Sofianou A, Fung TT, Tucker KL. Differences in diet pattern adherence by nativity and duration of US residence in the Mexican-American population. J Am Diet Assoc 2011; 111:1563-9.

23. Neumann AIP, Martins IS, Marcopito LF, Araujo EAC. Padrões alimentares associados a fatores de risco para doenças cardiovasculares entre residentes de um município brasileiro. Rev Panam Salud Pública 2007; 22:329-39.
24. Cunha DB, Almeida RMVR, Sichieri R, Pereira RA. Association of dietary patterns with BMI and waist circumference in a low-income neighbourhood in Brazil. Br J Nutr 2010; 104:908-13.

25. Kjøllesdal MR, Holmboe-Ottesen G, Mosdøl A, Wandel M. The relative importance of socioeconomic indicators in explaining differences in BMI and waist:hip ratio, and the mediating effect of work control, dietary patterns and physical activity. Br J Nutr 2010; 104:1230-40.

26. Duvigneaud N, Wijndaele K, Matton L, Philippaerts R, Lefevre J, Thomis M, et al. Dietary factors associated with obesity indicators and level of sports participation in Flemish adults: a crosssectional study. Nutr J 2007; 6:26.

27. Pereira LO, Francischi RP, Lancha Jr. AH. Obesidade: hábitos nutricionais, sedentarismo e resistência à insulina. Arq Bras Endocrinol Metab 2003; 47:111-27.

28. Sichieri R. Dietary patterns and their associations with obesity in the Brazilian city of Rio de Janeiro. Obes Res 2002; 10:42-8.

29. Yabanci N, Gocgeldi E, Simsek I, Kilic S. Prevalence of obesity, abdominal obesity and the associated factors among a group of Turkish adults. Pak J Med Sci 2010; 26:21-2.

30. McNaughton SA, Mishra GD, Stephen AM, Wadsworth MEJ. Dietary patterns throughout adult life are associated with body mass index, waist circumference, blood pressure, and red cell folate. J Nutr 2007; 137:99-105.

31. Chiara VL, Sichieri R, Carvalho TSF. Teores de ácidos graxos trans de alguns alimentos consumidos no Rio de Janeiro. Rev Nutr 2003; 16:227-33.

32. Rossi M, Negri E, Bosetti C, Maso LD, Talamini R, Giacosa A, et al. Mediterranean diet in relation to body mass index and waist-to-hip ratio. Public Health Nutr 2007; 11:214-7.

33. Newby PK, Muller D, Hallfrisch J, Qiao N, Andres R, Tucker KL. Dietary patterns and changes in body mass index and waist circumference in adults. Am J Clin Nutr 2003; 77:1417-25.

34. Olinto MTA, Gigante DP, Horta B, Silveira V, Oliveira I, Willett W. Major dietary patterns and cardiovascular risk factors among young Brazilian adults. Eur J Nutr 2012; 51:281-91

Submitted on 21/Nov/2012

Final version resubmitted on 23/May/2013

Approved on 09/Sep/2013 